\title{
Analisis Penetapan Nilai Jual Objek Pajak Terhadap Penerimaan Pajak Bumi Dan Bangunan Di Kabupaten Minahasa Tenggara
}

\author{
Oleh : \\ Nola Lavenia Watak \\ Fakultas Ekonomi Dan Bisnis \\ Universitas Sam Ratulangi Manado \\ Email : nola.watak@ymail.com
}

\begin{abstract}
Property Tax is one tax which is managed by the local government. Which is the only property tax in Indonesia, because most of the revenue is income areas, among others, are also used for the provision of facilities enjoyed by the central government and local government. Bases of land and building tax is the taxable value. The purpose of this study is to analyze Determination of taxable value against land and building tax in Southeast Minahasa Regency. The object of this research is 3 Southeast Minahasa District in the District Ratahan, District Pasan, and the District of East Ratahan. The data collection techniques in this study is a field study in the Department of Revenue in Southeast Minahasa regency. This research uses descriptive method. Based on the research results, the authors concluded that the three districts are districts Ratahan, Pasan, and Ratahan East where the districts are located in the city center in Southeast Minahasa Regency, strategic location and generates economic value. So it has a high contribution to the reception in Southeast Minahasa regency. Department of Revenue is responsible for determining the tax object selling value needs to improve the assessment and pengelolahan data, especially between the sale value of the tax object selling prices that occurred in the community so that more relevant determination.
\end{abstract}

Keywords: Determination of tax object selling value, Property tax

\section{PENDAHULUAN}

Pajak adalah iuran rakyat kepada Negara berdasarkan undang-undang (yang dapat dipaksakan) dengan tidak mendapat jasa timbal balik (kontraprestasi) yang langsung dapat ditunjukan dan yang digunakan untuk membayar pengeluaran umum. Pajak sebagai salah satu sumber pemerintah dalam negeri merupakan sektor potensial, penerimaan sektor pajak ini dimanfaatkan oleh pemerintah untuk membangun sarana dan prasarana kepentingan umum salah satunya Pajak Bumi dan Bangunan (PBB0.

PBB merupakan satu-satunya pajak properti di Indonesia sebagai pajak ojektif, yaitu pajak negara yang sebagian besar penerimaanya merupakan pendapatan daerah yang antara lain dipergunakan untuk penyediaan fasilitas yang juga dinikmati oleh pemerintah pusat maupun pemerintah daerah. Dasar pengenaan Pajak Bumi dan Bangunan adalah Nilai Jual Objek Pajak (NJOP).

Nilai Jual Objek Pajak adalah harga rata-rata yang diperoleh dari transaksi jual-beli, Nilai Jual Objek Pajak ditentukan dengan menggunakan perbandingan harga dengan objek lain yang sejenis atau nilai perolehan atau Nilai Jual Ojek Pajak pengganti. 
penerimaan PBB mengalami kenaikan, disebabkan oleh nilai jual objek pajak (NJOP) yang menjadi dasar pengenaan PBB di Kabupaten Minahasa Tenggara karena peningkatan jumlah penduduk yang diikuti permintaan terhadap bumi dan bangunan yang semakin tinggi sehingga meningkatkan harga jual bumi (tanah) dan bangunan. Juga dikarenakan pada lokasi objek pajak yang strategis atau letaknya di depan jalan utama, dan pemanfataannya untuk menghasilkan nilai ekonomis seperti usaha perdangangan, dan lain-lain.

Kabupaten Minahasa Tenggara merupakan salah satu kabupaten yang ada di Provinsi Sulawesi Utara yang memiliki 12 Kecamatan. Namun dari 12 kecamatan ini ada beberapa kecamatan yang berkotribusi cukup besar terhadap penerimaan PBB di Kabupaten Minahasa Tenggara yaitu Kecamata Ratahan, Pasan, dan Ratahan Timur. Karena memiliki kegiatankegiatan yang menghasilkan nilai perekonomian dimasing-masing kecamatan tersebut. Oleh karena itu, pajak merupakan fenomena yang selalu berkembang di masyarakat.

Tujuan Penelitian ini adalah untuk Mengetahui Penetapan Nilai Jual Objek Pajak (NJOP) Terhadap Pajak Bumi dan Bangunan di Kabupaten Minahasa Tenggara yang ada di 3 kecamatan yaitu kecamatan Ratahan, Kecamatan Pasan dan Kecamatan Ratahan Timur.

\section{TINJAUAN PUSTAKA}

Akuntansi merupakan salah satu komponen yang memiliki peranan penting bagi perusahaan. Menurut Riahi dan Belkaoui (2011:54), peranan dari akuntansi adalah untuk memberikan informasi mengenai perilaku ekonomi yang di akibatkan oleh aktivitas-aktivitas perusahaan dalam lingkungannya.

Menurut Muljono ( 2009:1) Akuntansi yang berkaitan dengan perhitungan perpajakan dan mengacu pada peraturan dan perundang-undang perpajakan beserta aturan pelaksanaannya, disebut akuntansi pajak.

Menurut Suprianto (2013:1) Pajak merupakan iuran atau pungutan wajib yang dipungut oleh pemerintah dari masyarakat wajib pajakuntuk menutupi pengeluaran rutin negara dan biaya pembangunan tanpa balas jasa yang dapat ditunjuk secara langsung. Namun secara logika pajak yang dibayar oleh masyarakat tersebut mempunyai dampak secara langsung terhadap kesejahteraan masyarakat seperti pembangunan jalan, jembatan, dan tempat-tempat umum lainnya.

Menurut Iiyas dan Burton (2013:13) menyatakan bahwa Dalam literatur pajak, sering disebutkan pajak mempunyai dua fungsi, yaitu fungsi budgeter dan fungsi regulerend. Namun dalam perkembangannya, fungsi pajak tersebut dikembangkan dan ditambah dua fungsi lagi, yaitu fungsi demokrasi dan fungsi redistribusi.

\section{Fungsi budgeter}

2.Fungsi regulerend

3.Fungsi demokrasi

4.Fungsi distribusi

Menurut Undang-Undang Nomor 12 Tahun 1985 tentang Pajak Bumi dan Bangunan sebagaimana telah diubah dengan Undang-Undang Nomor 12 Tahun 1994. PBB lahir untuk menyempurnakan pengenaan Ipeda dan pajak-pajak lain yang dianggap tumpang tindih, seperti pajak rumah tangga, pajak kekayaan, pajak jalan, dan lain-lain. PBB adalah pajak pusat yang hasilnya diberikan kepada Pemerintah Deerah.

Menurut Waluyo, (2011 : 201) pengertian Bumi adalah permukaan bumi dan tubuh bumi yang ada dibawahnya, sedangkan bangunan adalah kontruksi teknik yang ditanam atau dilekatkan secara tetap pada tanah dan perairan. Klasifikasi objek pajak oleh Meteri Keuangan, yang dimaksud dengan klasifikasi bumi dan bangunan adalah pengelompokan bumi dan bangunan 
menurut nilai jualnya dan digunakan sebagai pedoman serta untuk memudahkan penghitugan pajak yang terutang. Dalam menentukan klasifikasi bumi dan tanah diperhatikan faktor-faktor seperti: letak, peruntukan, pemanfaatan, dan kondisi lingkungan.

Menurut Resmi (2011:233) Nilai Jual Objek Pajak (NJOP) merupakan dasar pengenaan PBB. Besarnya NJOP ditetapkan dengan pengklasifikasian atau penggolongan nilai jual rata-rata bumi berupa tanah dan bangunan.

Penetapan Nilai Jual Objek Pajak

Pendekatan Penilaian

1. Pendekatan data Pasar (Market Data Approach)

Pendekatan data pasar dilakukan dengan cara membandingkan objek pajak yang akan dinilai dengan objek pajak lain yang sejenis yang nilai jualnya sudah diketahui dengan melakukan penyesuaian yang dipandang perlu.

2. Pendekatan Biaya ( Cost Approach)

Pendekatan biaya digunakan untuk penilaian bangunan, yaiut dengan cara memperhitungankan biaya-biaya yang dikeluarkan untuk membuat bangunan baru objek yang dinilai dan dikurangi penyusutan.

3. Pendekatan Kapitalisasi Pendapatan (Income Approach).

Pendekatan kapitalisasi pendapatan dilakukan dengan cara menghitung atau memproyeksikan seluruh pendapatan sewa/penjualan dalam satu tahun dari objek pajak yang dinilai dikurangi dengan kekosongan biaya operasi dan/atau hak pengusaha.

\section{Penelitian Terdahulu}

Ovelia, (2013) melakukan penelitian dengan judul Analisis penetapan Nilai Jual Objek Pajak dan Implikasinya Terhadap Penerimaan Pajak Bumi dan Bangunan di Kota Manado (studdi kasus di 4 kecamatan). Tujuan dari penelitian ini adalah unutk menganalisis penetapan NJOP dan bagaimana implikasinya terhadap PBB di kota manado. Hasil penelitian ini adalah 4 kecamatan memiliki penetapan NJOP tinggi. Dikarenakan letak objek pajak yang strategis dengan dominasi kegiatan perekonomian. Adreta, (2014) melakukan penelitian dengan judul Analisis Penentuan NJOP pajak Bumi dan Bangunan berdasarkan kelas pada kelurahan tinoor dua kec.Tomohon Utara. Tujuan dari penelitian ini adalah untuk mengetahui berapa besar penentuan NJOP PBB berdasarkan kelas pada kelurahan tinoor dua. Hasil dari penelitian ini adalah tinggi rendahnya NJOP tergantung pada objek pajak yaitu bumi dan bangunan, kelas NJOP Bumi dan Bangunan per M2.

Persamaan dengan penulis ini adalah teknik pengumpulan data didapat dari mengadakan observasi, wawancara, perhitungan PBBnya sama, dan menggunakan metode deskriptif. Perbedaannya adalah lokasi dan waktu berbeda.

\section{METODE PENELITIAN}

\subsection{Data}

Jenis Penelitian yang dilakukan yaitu Deskritif, yaitu membahas masalah dengan menguraikan, membandingkan suatu keadaan serta menjelaskan suatu keadaan sehingga dapat ditarik kesimpalnya. (Kuncoro 2009:112)

Tempat atau lokasi penelitian yang akan di lakukan di Kantor Dinas Pendapatan Daerah (DISPENDA) Kabupaten Minahasa Tenggara. Kompleks Perkantoran Blok A Jalan Raya Ratahan-Belang, Keluaran Wawali-Pasan kecamatan Ratahan. Dan waktu penelitian pada bulan maret sampai bulan Mei Tahun 2015.

Menurut Sugiyono, (2014: 85), Populasi adalah Wilayah generalisasi ysng terdiri atas: objek/subjek yang mempunyai kualitas dan karakteristik tertentu yang ditetapkan oleh peneliti 
untuk dipelajari dan kemudian ditarik kesimpulannya. Populasi dari penelitian ini adalah 3 kecamatan di Kabupaten Minahasa Tenggara yaitu seperti di bawah ini :

1. Kecamatan Ratahan

2. Kecamatan Pasan

3. Kecamatan Ratahan Timur

Menurut Sugiyono (2014: 81 ) Sedangkan Sampel adalah dari jumlah dan karakteristik yang dimiliki oleh polulasi tersebut. Peneliti menggunakan sampel yang diambil dari populasi itu adalah sebagai berikut :

1. Kecamatan Ratahan 15 wajib pajak sebesar $5.707 \mathrm{~m}^{2}$ dengan klasifikasi penggolongan kelas NJOP anatara kelas 80 samapai dengan84.

2. Kecamatan Pasan 15 wajib pajak sebesar $6.773 \mathrm{~m}^{2}$ dengan klasifikasi penggolongan kelas NJOP antara 92 sampai dengan 81.

3. Kecamatan Ratahan Timur 15 wajib pajak sebesar $6.372 \mathrm{~m}^{2}$ dengan klasifikasi penggolongan kelas NJOP antara 90-83.

\subsection{Metode Analisis}

Metode penelitian yang digunakan dalam penelitian ini adalah metode deskriptif, yaitu metode yang membahas masalah dengan menggunakan, membandingkan suatu keadaan serta menjelaskan suatu keadaan sehingga dapat ditarik kesimpulan dimana penulis ingin mencari jawaban secara mendasar tentang sebab akibat dengan menganalisis faktor-faktor terjadinya atau munculnya fenomena tertentu.

\section{HASIL ANALISIS DAN PEMBAHASAN}

\subsection{Hasil Analisis}

Kabupaten Minahasa Tenggara adalah salah satu kabupaten di provinsi Sulawesi Utara yang merupakan salah satu daerah pemekaran dari Kabupaten Minahasa Selatan. Kabupaten Minahasa Tenggara berdasarkan pembagian Wilayah aministratif Pemerintah Daerah dibagi dalam 12 Kecamatan dan 144 desa/kelurahan (135 Desa dan 9 kelurahan). Kabupaten Minahasa Tenggara di pimpin oleh seorang Bupati. Pada tingkat kecamatan dipimpin oleh Camat dan pada tingkat desa/kelurahan di pimpin oleh seorang Kepala Desa (Hukum Tua) / Lurah. Luas Kabupaten Minahasa Tenggara adalah $730.62 \mathrm{Km}^{2}$. Kabupaten Minahasa Tenggara memiliki topografi wilayah berupa berbukit-bukit atau pengunungan dan sebagian kecil daratan rendah bergelombang, serta memiliki sungai-sungai.

1. Visi : Terwujudnya optimalisasi penerimaan pendapatan daerah yang akuntabel dengan berorientasi pada pelayanan prima.

2. Msi :

a. Meningkatkan penerimaan pendapatan daerah

b. Meningkatkan kualitas pelayanan dan pengelolaaan pendapatan

c. Meningkatkan kualitas dan kinerja sumber daya aparatur dan organisasi

d. Meningkatkan kesadaran masyarakat sebagai wajib pajak

e. Meningkakan koordinasi, pengendalian dan pengawasan.

\section{Penetapan Nilai Jual Objek Pajak (NJOP) di Kecamatan Ratahan}

Di Kabupaten Minahasa Tenggara khususnya di Kecamatan Ratahan yang merupakan Ibu kota memiliki nilai jual objek pajak dari masing-masing wajib pajaknya yang berbeda-beda sesuai dengan kondisi yang dimiliki objek pajak yaitu berupa tanah dan bangunan. Kecamatan Ratahan sendiri banyak di dominasi dengan kegiatan perdangangan dan letak objek pajaknya yang strategis atau letak objek pajak berada di pinggiran jalan utama dan memiliki kegiatan- 
kegiatan yang memberikan nilai ekonomis yang cukup tinggi seperti, perkantoran swasta, pendidikan dan lain-lain.

Tabel 4.2 Penetapan NJOP Bumi dan Bangunan di Kecamatan Ratahan Tahun 2014

\begin{tabular}{|c|c|c|c|c|c|c|c|c|c|c|}
\hline \multirow{2}{*}{ No } & \multirow{2}{*}{$\begin{array}{l}\text { Nama } \\
\text { Wajib } \\
\text { Pajak }\end{array}$} & \multicolumn{4}{|l|}{ Bumi } & \multicolumn{4}{|c|}{ Bangunan } & \multirow{2}{*}{$\begin{array}{l}\text { NJOP Total } \\
\text { Bumi dan } \\
\text { Bangunan } \\
\text { (Rp) }\end{array}$} \\
\hline & & $\begin{array}{l}\text { Luas } \\
(\mathrm{m} 2)\end{array}$ & Kelas & $\begin{array}{l}\text { NJOP } \\
(\text { Rp/m) }\end{array}$ & $\begin{array}{l}\text { NJOP Bumi } \\
\text { (Rp) }\end{array}$ & $\begin{array}{l}\text { Luas } \\
(\mathrm{m} 2)\end{array}$ & Kelas & $\begin{array}{l}\text { NJOP } \\
(\mathbf{R p} / \mathbf{m})\end{array}$ & $\begin{array}{l}\text { Bangunan } \\
\text { (Rp) }\end{array}$ & \\
\hline 1 & A & 300 & 82 & 48.000 & 14.400 .000 & 300 & 21 & 1.200 .000 & 360.000 .000 & 374.400 .000 \\
\hline 2 & B & 447 & 83 & 36.000 & 16.092 .000 & 240 & 21 & 1.200 .000 & 288.000 .000 & 304.092 .000 \\
\hline 3 & $\mathrm{C}$ & 363 & 80 & 82.000 & 29.766 .000 & 200 & 25 & 595.000 & 119.000 .000 & 148.766 .000 \\
\hline 4 & D & 364 & 80 & 82.000 & 29.848 .000 & 150 & 25 & 595.000 & 89.250 .000 & 119.098 .000 \\
\hline 5 & E & 908 & 83 & 36.000 & 32.688 .000 & 100 & 23 & 823.000 & 82.300 .000 & 114.988 .000 \\
\hline 6 & $\mathrm{~F}$ & 394 & 83 & 36.000 & 14.184 .000 & 100 & 22 & 968.000 & 96.800 .000 & 110.984 .000 \\
\hline 7 & $\mathrm{G}$ & 224 & 81 & 64.000 & 14.336 .000 & 78 & 21 & 1.200 .000 & 93.600 .000 & 107.936 .000 \\
\hline 8 & $\mathrm{H}$ & 440 & 82 & 48.000 & 21.120 .000 & 54 & 23 & 823.000 & 44.442 .000 & 65.562 .000 \\
\hline 9 & I & 462 & 83 & 36.000 & 16.632 .000 & 60 & 25 & 595.000 & 35.700 .000 & 52.332 .000 \\
\hline 10 & $\mathrm{~J}$ & 214 & 81 & 64.000 & 13.696 .000 & 42 & 25 & 595.000 & 24.990 .000 & 38.686 .000 \\
\hline 11 & $\mathrm{~K}$ & 323 & 83 & 36.000 & 11.628 .000 & 60 & 27 & 429.000 & 25.740 .000 & 37.420 .000 \\
\hline 12 & $\mathrm{~L}$ & 231 & 80 & 82.000 & 18.942 .000 & 40 & 27 & 429.000 & 17.160 .000 & 36.102 .000 \\
\hline 13 & M & 187 & 80 & 82.000 & 15.334 .000 & 30 & 27 & 429.000 & 12.870 .000 & 28.204 .000 \\
\hline 14 & $\mathrm{~N}$ & 400 & 83 & 36.000 & 14.440 .000 & 30 & 28 & 365.000 & 10.950 .000 & 25.390 .000 \\
\hline 15 & $\mathrm{O}$ & 450 & 84 & 27.000 & 12.150 .000 & 20 & 27 & 429.000 & 8.580 .000 & 20.730 .000 \\
\hline Total & & & & & 275.154 .000 & & & & 1.309 .382 .000 & 1.584 .690 .000 \\
\hline
\end{tabular}

Sumber data: Data Dispenda, 2014

Berdasarkan data yang ada,didapat bahwa NJOP bumi (tanah) di Kecamatan Ratahan memiliki kelas tertinggi adalah 80 dengan nilai jual objek pajak (NJOP) sebesar Rp.82.000/m². Dan disusul dengan kelas 81 dengan nilai jual objek pajak sebesar Rp 64.000/ $\mathrm{m}^{2}$, kelas 82 dengan

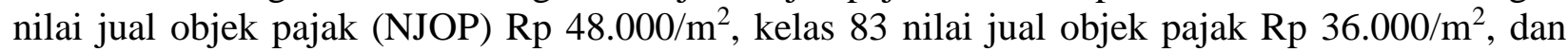
kelas 84 dengan nilai jual objek pajak sebesar Rp 27.000/ $\mathrm{m}^{2}$. Berbeda dengan NJOP Bangunan memiliki kelas NJOP yang bervariasi. Nilai jual objek pajak yang paling tinggi yaitu kelas 21 dengan nilai jual objek pajak $\mathrm{Rp} 1.200 .000 / \mathrm{m}^{2}$ dan terendah ada di kelas 28 dengan nilai jual objek pajak bangunannya Rp $365.000 / \mathrm{m}^{2}$. Total NJOP masing-masing objek yang menjadi dasar perhitungan dari PBB nantinya.

Penetapan Nilai Jual ObjekPajak (NJOP) di Kecamatan Pasan

Penetapan NJOP di kecamatan Pasan juga sebagai kecamatan yang sangat berperan penting dalam penerimaan PBB. Kecamatan ini memiliki klasifikasi atau kelas NJOP yang berbeda-beda baik bumi ataupun bangunan. 
Tabel 4.3 Penetapan NJOP Bumi dan Bangunan di Kecamatan Pasan Tahun 2014

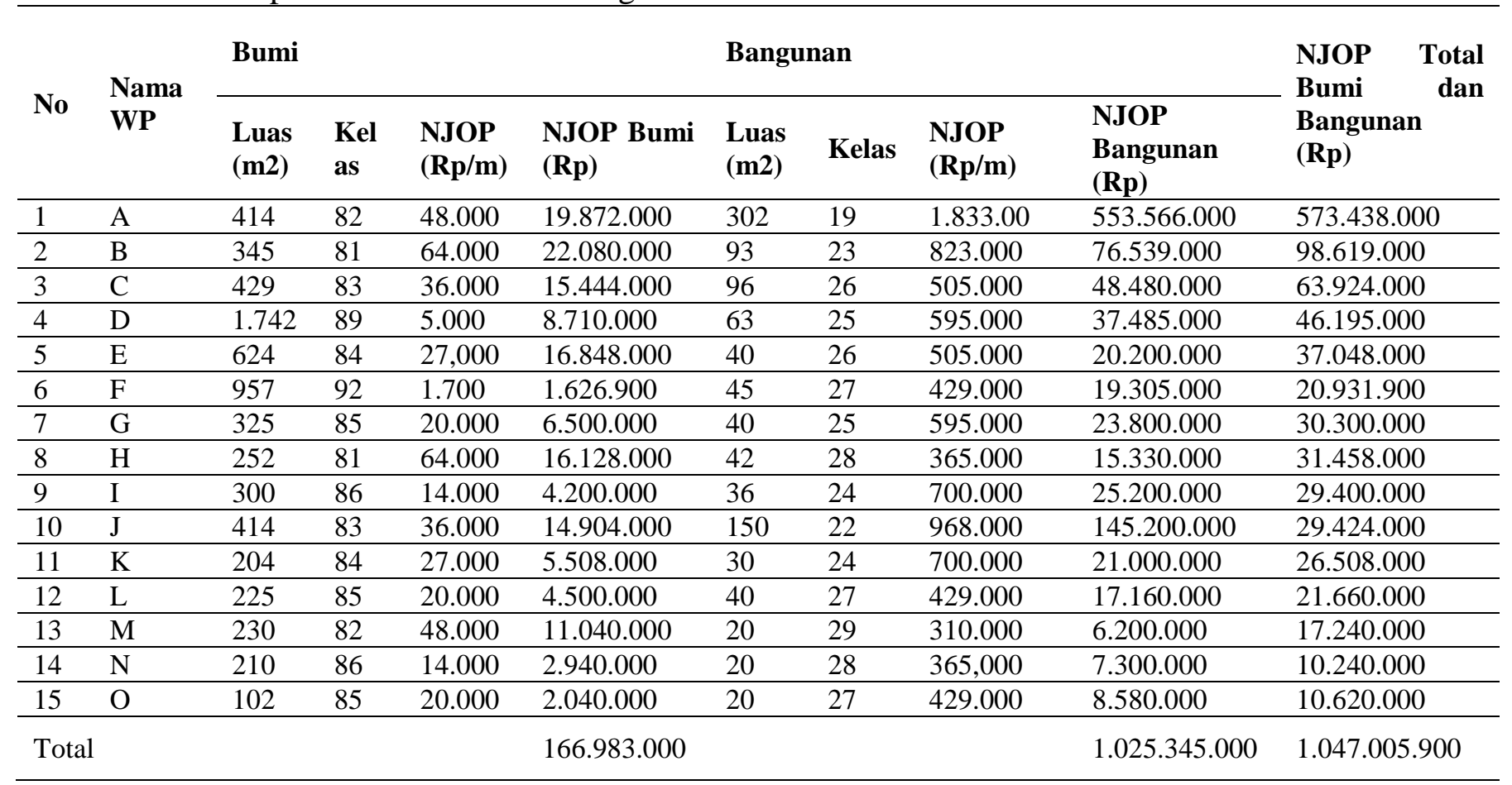

Sumber data: Data Dispenda, 2014

Berdasarkan data yang ada di dapat bahwa Kecamatan Pasan nilai jual objek pajak (NJOP) untuk Bumi (tanah) yang tertinggi ada di kelas 81 yaitu Rp 64.000/ $\mathrm{m}^{2}$, dan kelas 82, 83, 84, 85, 86, 89 dan terakhir kelas paling rendah 92 dengan nilai jual objek pajaknya masing-masing yaitu

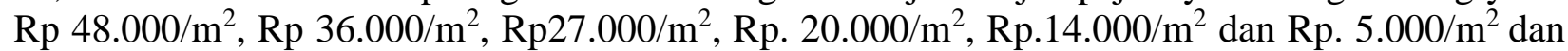
yang paling terendah NJOP-nya Rp.1.700/m² dengan luas tanah yang berbeda-beda. Dalam penetapan NJOP Bangunan di kecamatan Pasan sendiri NJOP tertinggi berada di kelas 19 sebesar Rp. $1.833 .000 / \mathrm{m}^{2}$ dan terendah berada di kelas 29 sebesar Rp. $310.000 / \mathrm{m}^{2}$. Setelah masingmasing nilai jual objek bumi dan bangunan di dapat, maka kita dapat melihat bahwa total NJOP keseluruhan yang tertinggi ada di wajib pajak A yaitu Rp. 573.438.000 dan terendah di wajib pajak O dengan total NJOP sebesar Rp. 10.620.00.

\section{Penetapan Nilai Jual Objek Pajak di Kecamatan Ratahan Timur}

Kecamatan Ratahan Timur juga merupakan salah satu Kecamatan yang memberikan Kontribusi cukup dalam hal penerimaan PBB. 
Tabel 4.4 Penetapan Nilai Jual Objek Pajak di Kecamatan Ratahan Timur Tahun 2014

\begin{tabular}{|c|c|c|c|c|c|c|c|c|c|c|}
\hline No & $\begin{array}{l}\text { Nama } \\
\text { WP }\end{array}$ & $\begin{array}{l}\text { Luas } \\
\text { (m2) }\end{array}$ & Kelas & $\begin{array}{l}\text { NJOP } \\
\text { (Rp/m) }\end{array}$ & $\begin{array}{l}\text { NJOP } \\
\text { (Rp) }\end{array}$ & $\begin{array}{l}\text { Luas } \\
(\mathrm{m} 2)\end{array}$ & Kelas & $\begin{array}{l}\text { NJOP } \\
\text { (Rp/m) }\end{array}$ & $\begin{array}{l}\text { NJOP } \\
\text { Bangunan } \\
\text { (Rp) }\end{array}$ & $\begin{array}{lr}\text { NJOP } & \text { Total } \\
\text { Bumi } & \text { dan } \\
\text { Bangunan } & (\mathrm{Rp})\end{array}$ \\
\hline 1 & A & 160 & 90 & 3.500 & 560.000 & 48 & 24 & 1.866 .667 & 89.600 .016 & 90.160 .016 \\
\hline 2 & B & 1.750 & 85 & 20.000 & 35.000 .000 & 36 & 27 & 429.000 & 15.444 .000 & 50.444 .000 \\
\hline 5 & $\mathrm{E}$ & 378 & 84 & 27.000 & 10.206 .000 & 36 & 27 & 429.000 & 15.444 .000 & 25.650 .000 \\
\hline 6 & $\mathrm{~F}$ & 230 & 87 & 10.000 & 2.300 .000 & 30 & 25 & 595.000 & 17.850 .000 & 20.150 .000 \\
\hline 7 & G & 345 & 89 & 27.000 & 9.315 .000 & 30 & 27 & 429.000 & 12.870 .000 & 22.185 .000 \\
\hline 8 & $\mathrm{H}$ & 520 & 84 & 27.000 & 14.040 .000 & 65 & 24 & 700.000 & 4.550 .000 & 18.590 .000 \\
\hline 9 & I & 300 & 85 & 20.000 & 6.000 .000 & 30 & 28 & 365.000 & 10.950 .000 & 16.950 .000 \\
\hline 10 & $\mathrm{~J}$ & 136 & 85 & 20.000 & 2.720 .000 & 30 & 27 & 429.000 & 12.870 .000 & 15.590 .000 \\
\hline 15 & $\mathrm{O}$ & 110 & 84 & 27.000 & 2.970 .000 & 16 & 26 & 505.000 & 8.080 .000 & 11.050 .000 \\
\hline Total & & & & & 115.062 .000 & & & & 273.857 .016 & 388.919 .016 \\
\hline
\end{tabular}

Sumber Data :Data Dispenda, 2014

Berdasarkan data yang ada didapat bahwa NJOP bumi (tanah) di kecamatan Ratahan

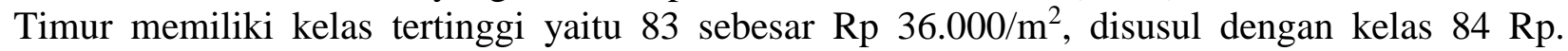
27.000. berbeda dengan NJOP Bangunan memiliki kelas tertinggi yaitu 24 sebesar $1.866 .667 / \mathrm{m}^{2}$ dan terendah di kelas 30 yaitu sebesar Rp. $264.000 / \mathrm{m}^{2}$. Dan sesuai dengan didapat total NJOP keseluruhan yang paling tinggi ada di wajib pajak A sebesar Rp. $90.160 .016 / \mathrm{m}^{2}$ dan terendah yaitu wajib pajak O dengan total NJOP sebesar Rp. $11.050 .000 / \mathrm{m}^{2}$. Total NJOP inilah yang menjadi dasar perhitungan PBB.

\section{Perhitungan Pajak Bumi dan Bangunan di Kecamatan Ratahan}

Nilai jual objek pajak (NJOP) yang sebelumnya telah di tetapakan oleh masing-masing objek pajak di kecamatan Ratahan menjadi dasar perhitungan PBB. Dimana NJOP tersebut dikurangi dengan nilai jual objek pajak tidak kena pajak (NJOPTKP) dengan standar di Kabupaten Minahasa Tenggara adalah sebesar Rp. 10.000.000 maka diperoleh nilai jual objek pajak sebagai dasar perhitungan PBB.selanjutnya dikalikan dengan persentasi nilaijual kena pajak (NJKP) diman NJOP di atas satu milyar dikenakan tarif sebesar 40\% dan dibawa satu milyar tarif sebesar 20\%. Dan setelah itu NJKP dikalikan dengan tariff PBB sebesar 0,5\% maka akan didapat PBB terhutangnya. Tabel dibawah ini merupakan perhitungan PPB di kecamatan Ratahan : 
Tabel 4.5 Perhitungan PBB di Kecamatan Ratahan Tahun 2014

\begin{tabular}{|c|c|c|c|c|c|c|}
\hline $\begin{array}{l}\text { Nama } \\
\text { Wajib } \\
\text { Pajak }\end{array}$ & $\begin{array}{l}\text { NJOP Total } \\
\text { Bumi dan } \\
\text { Bangunan } \\
\text { (Rp) }\end{array}$ & $\begin{array}{l}\text { NJOPTK } \\
\text { P (Rp) }\end{array}$ & $\begin{array}{l}\text { NJOP untuk } \\
\text { Penghitungan } \\
\text { PBB (Rp) }\end{array}$ & $\begin{array}{l}\% \\
\text { NJKP }\end{array}$ & NJKP (Rp) & $\begin{array}{l}\text { PBB Terutang } \\
\text { (Rp) }\end{array}$ \\
\hline A & 374.400 .000 & $\begin{array}{l}10.000 .00 \\
0\end{array}$ & 364.400 .000 & $20 \%$ & 72.880 .000 & 364.400 \\
\hline B & 304.092 .000 & $\begin{array}{l}10.000 .00 \\
0\end{array}$ & 294.092 .000 & $20 \%$ & 58.818 .400 & 294.092 \\
\hline $\mathrm{C}$ & 148.766 .000 & $\begin{array}{l}10.000 .00 \\
0\end{array}$ & 138.766 .000 & $20 \%$ & 27.753 .200 & 138.766 \\
\hline D & 119.098 .000 & $\begin{array}{l}10.000 .00 \\
0\end{array}$ & 109.098 .000 & $20 \%$ & 21.819 .600 & 109.098 \\
\hline $\mathrm{E}$ & 114.988 .000 & $\begin{array}{l}10.000 .00 \\
0\end{array}$ & 104.988 .000 & $20 \%$ & 20.997 .600 & 104.988 \\
\hline $\mathrm{F}$ & 110.984 .000 & $\begin{array}{l}10.000 .00 \\
0\end{array}$ & 100.984 .000 & $20 \%$ & 20.196 .800 & 100.984 \\
\hline G & 107.936 .000 & $\begin{array}{l}10.000 .00 \\
0\end{array}$ & 97.936 .000 & $20 \%$ & 19.587 .200 & 97.936 \\
\hline $\mathrm{H}$ & 65.562 .000 & $\begin{array}{l}10.000 .00 \\
0\end{array}$ & 55.562 .000 & $20 \%$ & 11.112 .400 & 55.562 \\
\hline I & 52.332 .000 & $\begin{array}{l}10.000 .00 \\
0\end{array}$ & 42.332 .000 & $20 \%$ & 8.466 .400 & 42.332 \\
\hline $\mathrm{J}$ & 38.686 .000 & $\begin{array}{l}10.000 .00 \\
0\end{array}$ & 28.686 .000 & $20 \%$ & 5.737 .200 & 28.686 \\
\hline K & 37.420 .000 & $\begin{array}{l}10.000 .00 \\
0\end{array}$ & 27.420 .000 & $20 \%$ & 5.484 .000 & 27.420 \\
\hline $\mathrm{L}$ & 36.102 .000 & $\begin{array}{l}10.000 .00 \\
0\end{array}$ & 26.102 .000 & $20 \%$ & 5.220 .400 & 26.102 \\
\hline M & 28.204 .000 & $\begin{array}{l}10.000 .00 \\
0\end{array}$ & 18.204 .000 & $20 \%$ & 3.640 .800 & 18.204 \\
\hline $\mathrm{N}$ & 25.390 .000 & $\begin{array}{l}10.000 .00 \\
0\end{array}$ & 15.390 .000 & $20 \%$ & 3.078 .000 & 15.390 \\
\hline $\mathrm{O}$ & 20.730 .000 & $\begin{array}{l}10.000 .00 \\
0\end{array}$ & 10.730 .000 & $20 \%$ & 2.146 .000 & 10.730 \\
\hline Total & & & & & & 1.434 .690 \\
\hline
\end{tabular}

Sumber Data : Data Olahan

Berdasarkan tabel 4.5 Di atas kita dapat lihat bahwa perhitungan PBB yang tertinggi terdapat pada Wajib Pajak A yaitu sebesar Rp 364.400 dan di susul dengan objek pajak yang memiliki wajib pajak B dengan pembayaran PBB sebesar Rp. 294.092. Sedangkan yang paling rendah ada di wajib pajak O dengan pembayaran PBB sebesar Rp. 10.730.

Perhitungan Pajak Bumi dan Bangunan di Kecamatan Pasan

Perhitungan Pajak Bumi dan Bangunan dikecamatan Pasan dapat di lihat pada tabel dibawah ini : 
Tabel 4.6 Perhitungan PBB di Kecamatan Ratahan Tahun 2014

\begin{tabular}{|c|c|c|c|c|c|c|}
\hline $\begin{array}{l}\text { Nama } \\
\text { Wajib } \\
\text { Pajak }\end{array}$ & $\begin{array}{l}\text { NJOP } \\
\text { Total Bumi } \\
\text { dan } \\
\text { Bangunan } \\
\text { (Rp) }\end{array}$ & $\begin{array}{l}\text { NJOPTK } \\
\text { P (Rp) }\end{array}$ & $\begin{array}{l}\text { NJOP untuk } \\
\text { Penghitungan } \\
\text { PBB (Rp) }\end{array}$ & $\begin{array}{l}\% \\
\text { NJKP }\end{array}$ & NJKP (Rp) & Terutang \\
\hline A & 573.438 .000 & $\begin{array}{l}10.000 .00 \\
0\end{array}$ & 563.438 .000 & $20 \%$ & 112.687 .600 & 563.438 \\
\hline B & 98.619 .000 & $\begin{array}{l}10.000 .00 \\
0\end{array}$ & 88.619 .000 & $20 \%$ & 17.723 .800 & 88.619 \\
\hline $\mathrm{C}$ & 63.924 .000 & $\begin{array}{l}10.000 .00 \\
0\end{array}$ & 53.924 .000 & $20 \%$ & 10.784 .800 & 53.924 \\
\hline $\mathrm{D}$ & 46.195 .000 & $\begin{array}{l}10.000 .00 \\
0\end{array}$ & 36.195 .000 & $20 \%$ & 7.239 .000 & 36.195 \\
\hline $\mathrm{E}$ & 37.048 .000 & $\begin{array}{l}10.000 .00 \\
0\end{array}$ & 27.048 .000 & $20 \%$ & 5.409 .600 & 27.048 \\
\hline $\mathrm{F}$ & 31.458 .000 & $\begin{array}{l}10.000 .00 \\
0\end{array}$ & 21.458 .000 & $20 \%$ & 4.291 .600 & 21.458 \\
\hline $\mathrm{G}$ & 30.300 .000 & $\begin{array}{l}10.000 .00 \\
0\end{array}$ & 20.300 .000 & $20 \%$ & 4.060 .000 & 20.300 \\
\hline $\mathrm{H}$ & 29.424 .000 & $\begin{array}{l}10.000 .00 \\
0\end{array}$ & 19.424 .000 & $20 \%$ & 3.884 .800 & 19.424 \\
\hline I & 29.400 .000 & $\begin{array}{l}10.000 .00 \\
0\end{array}$ & 19.400 .000 & $20 \%$ & 3.880 .000 & 19.400 \\
\hline $\mathrm{J}$ & 26.508 .000 & $\begin{array}{l}10.000 .00 \\
0\end{array}$ & 16.508 .000 & $20 \%$ & 3.301 .600 & 16.508 \\
\hline K & 21.660 .000 & $\begin{array}{l}10.000 .00 \\
0\end{array}$ & 11.660 .000 & $20 \%$ & 2.332 .000 & 11.660 \\
\hline $\mathrm{L}$ & 20931900 & $\begin{array}{l}10.000 .00 \\
0\end{array}$ & 10.931 .900 & $20 \%$ & 2.186 .380 & 10.932 \\
\hline M & 17.240 .000 & $\begin{array}{l}10.000 .00 \\
0\end{array}$ & 7.240 .000 & $20 \%$ & 1.448 .000 & 7.240 \\
\hline $\mathrm{N}$ & 10.620 .000 & $\begin{array}{l}10.000 .00 \\
0\end{array}$ & 620.000 & $20 \%$ & 124.000 & 620 \\
\hline $\begin{array}{l}\mathrm{O} \\
\text { Total }\end{array}$ & 10.240 .000 & $\begin{array}{l}10.000 .00 \\
0\end{array}$ & 240.000 & $20 \%$ & 48.000 & $\begin{array}{l}240 \\
897.006\end{array}$ \\
\hline
\end{tabular}

Sumber Data :Data Olahan

Berdasarkan pada tabel 4.6 di atas, dapat kita lihat bahwa perhitungan PBB yang tertinggi terdapat pada objek pajak yang dimiliki wajib pajak A yaitu sebesar Rp. 563.438 yang harus dibayar.disusul dengan objek pajak dimiliki wajib pajak B sebesar Rp.88.619 dan seterusnya. Dan yang paling rendah terdapat pada wajib pajak O sebesar Rp.240.

Perhitungan Pajak Bumi dan Bangunan di Kecamatan Ratahan Timur

Perhitungan Pajak Bumi dan Bangunan (PBB) di Kecamatan Ratahan Timur dapat di lihat pada tabel di bawah ini : 
Tabel 4.7 Perhitungan PBB di Kecamatan Ratahan Timur Tahun 2014

\begin{tabular}{|c|c|c|c|c|c|c|}
\hline $\begin{array}{l}\text { Nama } \\
\text { Wajib } \\
\text { Pajak }\end{array}$ & $\begin{array}{lr}\text { NJOP } & \text { Total } \\
\text { Bumi } & \text { dan } \\
\text { Bangunan } & (\mathrm{Rp})\end{array}$ & $\begin{array}{l}\text { NJOPTK } \\
\text { P (Rp) }\end{array}$ & $\begin{array}{l}\text { NJOP untuk } \\
\text { Penghitungan } \\
\text { PBB (Rp) }\end{array}$ & \% NJKP & NJKP (Rp) & $\begin{array}{l}\text { PBB } \\
\text { Terutang } \\
\text { (Rp) }\end{array}$ \\
\hline A & 90.160 .016 & $\begin{array}{l}10.000 .00 \\
0\end{array}$ & 80.160 .016 & $20 \%$ & 16.032 .003 & 80.160 \\
\hline B & 50.444 .000 & $\begin{array}{l}10.000 .00 \\
0\end{array}$ & 40.444 .000 & $20 \%$ & 8.088 .800 & 40.444 \\
\hline $\mathrm{C}$ & 36.295 .000 & $\begin{array}{l}10.000 .00 \\
0\end{array}$ & 26.295 .000 & $20 \%$ & 5.259 .000 & 26.295 \\
\hline $\mathrm{D}$ & 29.619 .000 & $\begin{array}{l}10.000 .00 \\
0\end{array}$ & 19.619 .000 & $20 \%$ & 3.923 .800 & 19.619 \\
\hline $\mathrm{E}$ & 25.650 .000 & $\begin{array}{l}10.000 .00 \\
0\end{array}$ & 15.650 .000 & $20 \%$ & 3.130 .000 & 15.650 \\
\hline $\mathrm{F}$ & 20.150 .000 & $\begin{array}{l}10.000 .00 \\
0\end{array}$ & 10.150 .000 & $20 \%$ & 2.030 .000 & 10.150 \\
\hline G & 22.185 .000 & $\begin{array}{l}10.000 .00 \\
0\end{array}$ & 12.185 .000 & $20 \%$ & 2.437 .000 & 12.185 \\
\hline $\mathrm{H}$ & 18.590 .000 & $\begin{array}{l}10.000 .00 \\
0\end{array}$ & 8.590 .000 & $20 \%$ & 1.718 .000 & 8.590 \\
\hline I & 16.950 .000 & $\begin{array}{l}10.000 .00 \\
0\end{array}$ & 6.950 .000 & $20 \%$ & 1.390 .000 & 6.950 \\
\hline $\mathrm{J}$ & 15.590 .000 & $\begin{array}{l}10.000 .00 \\
0\end{array}$ & 5.590 .000 & $20 \%$ & 1.118 .000 & 5.590 \\
\hline K & 14.146 .000 & $\begin{array}{l}10.000 .00 \\
0\end{array}$ & 4.146 .000 & $20 \%$ & 829.200 & 4.146 \\
\hline $\mathrm{L}$ & 14.190 .000 & $\begin{array}{l}10.000 .00 \\
0\end{array}$ & 4.190 .000 & $20 \%$ & 838.000 & 4.190 \\
\hline M & 12.000 .000 & $\begin{array}{l}10.000 .00 \\
0\end{array}$ & 2.000 .000 & $20 \%$ & 400.000 & 2.000 \\
\hline $\mathrm{N}$ & 11.900 .000 & $\begin{array}{l}10.000 .00 \\
0\end{array}$ & 1.900 .000 & $20 \%$ & 380.000 & 1.900 \\
\hline $\begin{array}{l}\mathrm{O} \\
\text { Total }\end{array}$ & 11.050 .000 & $\begin{array}{l}10.000 .00 \\
0\end{array}$ & 1.050 .000 & $20 \%$ & 210.000 & $\begin{array}{l}1.050 \\
238.919\end{array}$ \\
\hline
\end{tabular}

Sumber Data : Data Olahan

Berdasarkan tabel 4.7 di atas dapat dilihat bahwa perhitungan PBB yang tertinggi terdapat pada objek pajak yang memiliki wajib pajak A yaitu sebesar Rp. 80.160 Dan disusul dengan objek pajak yang memiliki wajib pajak B dengan PBB yang harus dibayar sebesar Rp.40.444. dan yang paling terendah ada diwajib pajak O dengan pembayaran PBB sebesar Rp.1.050.

Setelah didapat hasil penetapan NJOP pada masing-masing kecamatan dapat dilihat bahwa semakin besar luas tanahnya maka NJOP bumi akan menyesuaikan yaitu semakin besar pula. 
Namun hal ini juga dilihat dari letaknya strategis (berada dijalan utama) dan bisa menghasilkan nilai ekonomis. Walaupun luas tanahnya kecil, jika objek pajaknya berada di posisi yang strategis atau berada di pinggiran jalan utama,dan memiliki nilai ekonomis dalam pengunanaanya, kelas NJOP akan menyesuaikan dan dapat menjadi tinggi juga. Misalnya di Kecamatan Ratahan luas tanah Wajib Pajak A sebesar $447 \mathrm{~m}^{2}$ memiliki kelas NJOP bumi 83 yaitu sebesar Rp. 36.000/m², dimana pada wajib pajak lain misalnya wajib pajak $\mathrm{K}$ dengan luasnya hanya $323 \mathrm{~m}^{2}$ dikenakan kelas yang sama yaitu 83 sebesar Rp. 36.000/m². Hal seperti ini menjadikan penetapan NJOP Bumi semakin tinggi demikiannya dengan NJOP bangunan sehingga penerimaan PBB-nya juga tinggi.

Berbeda dengan objek pajak yang posisinya terletak di bagian yang kurang strategis juga tidak memiliki pemanfaatan ekonomis. Misalnya di Kecamatan Ratahan timur pada wajib pajak $\mathrm{K}$ dengan luas tanah sebesar $560 \mathrm{~m}^{2}$ memiliki kelas 90 yaitu hanya $\mathrm{Rp} .3 .500 / \mathrm{m}^{2}$. Berbeda dengan Wajib Pajak E yang memiliki tanah dengan luas $378 \mathrm{~m}^{2}$,kelas buminya 84 dengan NJOP-nya sebesar Rp.27.000/m², sehingga penerimaan PBB-nya akan menyesuaikan dengan total NJOP secara keseluruhan Bumi dan Bangunan.

Penetapan NJOP yang telah ditetapkan akan menjadi dasar perhitungan PBB. Jika total NJOP bumi/bangunan tinggi, maka penerimaan PBB juga akan tinggi mengikuti besarnya NJOP. Demikian sebaliknya jika NJOP-nya rendah, penerimaan PBB juga akan rendah. Setelah melihat tiga kecamatan dalam penelitian ini, yaitu kecamatan Ratahan, Pasan, dan Ratahan Timur dimana kecamatan-kecamatan ini berada di pusat kota di Kabupaten Minahasa Tenggara, letaknya yang strategis dan menghasilkan nilai ekonomis.

Berdasarkan hasil penelitian mengenai Penetapan nilai jual objek pajak (NJOP) di 3 kecamatan Ratahan, Pasan, Ratahan Timur terhadap Penerimaan Pajak bumi dan bangunan di peroleh bahwa penerimaan PBB pertama berada pada kecamatan Ratahan sebesar Rp. 1.434.690, Kedua berada pada kecamatan Pasan sebesar Rp.897.006, dan yang ke tiga berada pada kecamatan Ratahan Timur sebesar Rp. 238.919.

\section{KESIMPULAN}

Dari hasil penelitian dapat di ambil kesimpulannya adalah sebagai berikut :

1. Penetapan NJOP di kecamatan Ratahan, Pasan, dan Ratahan Timur memiliki klasifikasi atau penggolongan kelasyang bervariasi baik bumi dan bangunan. Kelas yang NJOP tertinggi dimasing-masing kecamatan salah satunya dipengaruhi oleh letak objek pajaknya yang strategis atau berada di pinggiran jalan utama dan disebabkan karena penggunaan objek pajak untuk usaha perekonomian seperti perdangangan, perkantoran, jasa umum, dan lain-lain. Sehingga memiliki kontribusi yang tinggi terhadap penerimaan PBB di Kabupaten Minahasa Tenggara.

2. Berdasarkan penelitian penulis, aplikasi yang digunakan dalam perhitungan pentapan NJOP berdasarkan luas tanah dan bangunan, kalsifikasi kelas NJOP di hitung dalam aplikasi computer yaitu Sistem Informasi Manajemen Pajak Daerah ( SIMPD).

3. Dan berdasarkan hasil penelitian, yang diperoleh dari penerimaan PBB yang pertama pada Kecamatan Ratahan sebagai Ibu kota yang maju dengan penerimaan PBB sebesar Rp. 1.434.690,00, Kedua Kecamatan Pasan sebesar Rp. 897.006,00, dan yang ke Tiga Kecamatan Ratahan Timur yaitu sebesar Rp. 238.919,00.

Dari hasil penelitian dan kesimpulan diberikan saran adalah sebagai berikut :

1. Untuk meningkatkan penerimaan pajak bumi dan bangunan (PBB) di Kabupaten Minahasa Tenggara, Dinas Pendapatan Daerah perlu meningkatkan penilaian dan pengelolahan data 
khususnya antara nilai jual objek pajak (NJOP) dengan harga jual yang terjadi pada masyarakat sehingga penetapan NJOP lebih relevan.

2. Kiranya penelitian ini dapat menjadi bahan acuan bagi penelitian selanjutnya, agar supaya Pajak Daerah khususnya di PBB akan lebih berkontribusi terhadap Dispenda Kab.Minahasa Tenggara, sehingga akan selalu ada perubahan di setiap tahun penerimaan PBB.

3. Pemerintah sebaiknya mengontrol cara kerja terhadap instansi tersebut agar kedepannya lebih meningkat lagi kualitas kinerja seluruh pengawai di Dispenda Kab. Minahasa Tenggara.

\section{DAFTAR PUSTAKA}

Anastasia Diana, Lilis Setiawan. (2009). Perpajakan Indonesia. Andi. Yogyakarta.

liyas Wirawan B, Burton Richard. (2013). Hukum Pajak : Teori, Analisis, Dan Perkembangannya. Edisi 6.Salemba Empat. Jakarta

Lubis Irwanyah, Djuanda Gustin, Lubis Ardiansyah. (2010). Review Pajak Orang Prbadi dan OrangAsing. SalembaEmpat. Jakarta

Mardiasmo. (2011). Perpajakan. Edisi Revisi. Andi. Jakarta

Mardiasmo. (2009). Perpajakan. Edisi Revisi. Andi. Jakarta

Muljono. (2009). Akuntansi Pajak. Andi. Yogyakarta.

Novryadi.(2012). Penilaian Individual Objek Pajak PBB. Jakarta http://novryadisidauruk.blogspot.com/2012/08/penilaian-individual objek-pajak pbb.html. Diakses Mei, 05, 2015_Ovelia.(2013). Analisis Penetapan Nilai Jual Objek Pajak dan Implikasinya Terhadap Pajak Bumi dan Bangunan Di Kota Manado (Studi kasus 4 Kecamatan).

Rangian. (2014). Analisis Penentuan Nilai Jual Objek Pajak (NJOP) Pajak Bumi dan Bangunan Berdasarkan Kelas Pada Kelurahan Tinoor Dua Kecamatan Tomohon Utara.

Resmi Siti. (2012a). Perpajakan: Teori dan Kasus. Edisi 6. Selemba Empat. Jakarta Resmi Siti. (2012b). Perpajakan: Teori dan Kasus. Edisi 6. Selemba Empat. Jakarta Indrawan Rully, Yaniawati Poppy. (2014). Metodologi Penelitian Kunatitatif, Kualitatif, dan Campuran Untuk Manajemen Pembangunan dan Pendidikan. PT. Refika Aditama. Bandung

Sugiyono. (2014). Penelitian kuantitatif Kualitatif dan R\&D. Alfabeta. Bandung

Sutedi. (2013). Hukum Pajak. Sinar Grafika. Jakarta

Suprianto. (2013).Hukum Pajak Indonesia. Penerbit Graha Ilmu. Jakarta

Waluyo. (2013). Perpajakan indonesia. Edisi 11. Selemba Empat. Jakarta

Waluyo. (2011). Perpajakan Indonesia. Edisi 10. Penerbit Salemba Empat. Jakarta 